\title{
$\mathrm{Si}_{3} \mathrm{~N}_{4}$ 反応焼結体と溶鉄との反応における 溶鉄中の溶解酸素の影響
}

\author{
高橋達人・西正明
}

(日本鋼管（株）福山研究所)

\section{Influence of Dissolved Oxygen on the Reaction between Molten Iron and Reaction-Bonded $\mathbf{S i}_{3} \mathbf{N}_{4}$}

\author{
Tatsuhito TAKAHASHI and Masaaki NISHI \\ $\left(\begin{array}{l}\text { Fukuyama Research Laboratories, Nippon Kokan K. K. } \\ \text { 1, Kokan-cho, Fukuyama-shi } 721\end{array}\right)$
}

Fundamental investigations of the reaction between $\mathrm{Si}_{3} \mathrm{~N}_{4}$ and molten iron have shown that $\mathrm{Si}_{3} \mathrm{~N}_{4}$ material is desirable in steelmaking process. This paper describes the influence of dissolved oxygen in iron on the corrosion of reaction-bonded $\mathrm{Si}_{3} \mathrm{~N}_{4}$. The results are as follows:

$\mathrm{Si}_{3} \mathrm{~N}_{4}$ specimens dipped into iron containing more-than-300-ppm dissolved oxygen for 30 minutes at $1630^{\circ} \mathrm{C}$ and rotated at $300 \mathrm{rpm}$ were not attacked. However, molten iron of less-than-300-ppm oxygen attacked $\mathrm{Si}_{3} \mathrm{~N}_{4}$ as oxygen contents decreased. Optical microscope and EPMA observations showed the formation of 50-150- $\mu$ m thick $\mathrm{SiO}_{2}$ layer on the $\mathrm{Si}_{3} \mathrm{~N}_{4}$ surface which did not corrode. Otherwise, there was none of the thick layer on specimens dipped in below-300-ppm-oxygen iron. This reaction mechanism was discussed thermodynamically. Iron with a high dissolved oxygen level forms a large amount of $\mathrm{SiO}_{2}$ at the beginning of the reaction, which acts as a protection layer on the $\mathrm{Si}_{3} \mathrm{~N}_{4}$ surface. On the other hand, a low dissolved oxygen level iron causes the $\mathrm{Si}$ of $\mathrm{Si}_{3} \mathrm{~N}_{4}$ to dissolve into iron without $\mathrm{SiO}_{2}$ formation.

[Received July 7, 1986 ; Accepted July 16, 1987]

Key-words : Silicon nitride, $\mathrm{Si}_{3} \mathrm{~N}_{4}$, Molten iron, Dissolved oxygen, Corrosion, $\mathrm{SiO}_{2}$ layer

\section{・1. 緒 言}

窒化ケイ素 $\left(\mathrm{Si}_{3} \mathrm{~N}_{4}\right)$ は，炭化ケイ素 $(\mathrm{SiC})$ やサイ アロンと同椂に, 非酸化物系の高温構造材料の一つであ り，既にエンジン用部品をはじめとして，種々の応用が 試みられている. また, 鉄鋼用の耐火物として, 凝固シェ ルの生成点にあたる水平連続鋳造のブレークリング1にに $\mathrm{Si}_{3} \mathrm{~N}_{4}$ 反応焼結体が用いられはじめた。

一方，耐火物之溶融スラグ，あるいは溶鉄との反応に 関しては，過去，数多くの報告がなされているが，その 報告は主に酸化物系材料のものであり, 非酸化物系材料 と溶鉄との反応になるとほとんど報告されていない現状 である。その中で萇輪ら ${ }^{2), 3}$ は, $\mathrm{Si}_{3} \mathrm{~N}_{4}$ と溶鉄との反応 を主に速度論的観点から明らかにしており，また前田 ら" も，溶鉄による $\mathrm{Si}_{3} \mathrm{~N}_{4}$ の浸食について報告している. また一方で, $\mathrm{SiC}$ などの非酸化物系材料の損耗は, 雾 囲気中の酸素濃度に大きく依存することが知られてい $3^{5), 6)}$. 溶鉄においては前述の㝨輪らが, 炭素飽和鉄及 び未脱酸溶鉄において, $\mathrm{Si}_{3} \mathrm{~N}_{4}$ の反応速度が低下する傾 向を観察しているものの, 具体的な溶鉄中の溶解酸素濃 度との関係については明らかにされていない。

そこで，ここでは， $\mathrm{Si}_{3} \mathrm{~N}_{4}$ 材料を鉄鋼用耐火材料とし
て使用するための基礎的な検討として, 溶解酸素濃度を $37 \mathrm{ppm}$ から $942 \mathrm{ppm}$ までの広い範囲にわたって変化さ せた溶鉄に, $\mathrm{Si}_{3} \mathrm{~N}_{4}$ 反応焼結体を回転浸漬させ，試験し た. 更に, 浸漬試料の微構造観察を行い, 検討を加える ことにより, $\mathrm{Si}_{3} \mathrm{~N}_{4}$ と溶鉄との反応機構について考察し た.

\section{2. 試料及び試験方法}

\section{1 試 料}

試料は, 浸漬試験用に $20 \mathrm{~mm} \phi \times 150 \mathrm{~mm} L$ の形状に 研削加工した表 1 に示す $\mathrm{Si}_{3} \mathrm{~N}_{4}$ 反応焼結体を用いた.

\section{2 試験方法}

実験には図 1 に示す管状炉を用いた。試験方法は，ま ずこの管状炉内に設置した $\mathrm{Al}_{2} \mathrm{O}_{3}$ るつぼ内で約 $3 \mathrm{~kg} の$ 純鉄 $(\mathrm{C}: 0.004 \%, \mathrm{Si}: \leqq 0.01 \%, \mathrm{Mn}: 0.03 \%, \mathrm{P}$ : $0.003 \%, \mathrm{~S}: 0.002 \%)$ を溶解し, 溶解後, 溶鉄中の溶 解酸素量を $37 \mathrm{ppm}$ から $942 \mathrm{ppm}$ の範囲で変化させた. 溶解酸素量の制御にはカーボン及び酸化第二鉄 $\left(\mathrm{Fe}_{2} \mathrm{O}_{3}\right)$ 試薬を用いた，溶鉄を $1630^{\circ} \mathrm{C}$ の温度に保持した後, る つぼの直上で溶鉄とほぼ同じ温度に予熱してある試料を $300 \mathrm{rpm}$ の速さで回転させながら溶鉄中に $50 \mathrm{~mm}$ 浸漬 
Table 1. Properties of reaction-bonded $\mathrm{Si}_{3} \mathrm{~N}_{4}$.

\begin{tabular}{ll}
\hline $\begin{array}{l}\text { Chemical Composition }(\mathscr{S}) \\
\text { SizN4 } \\
\text { SiO2 }\end{array}$ & 96 \\
\hline Apperent Porosity $(\Phi)$ & 3 \\
Bulk Density $\left(\mathrm{g} / \mathrm{cm}^{3}\right)$ & $15-18$ \\
Cold M.O.R. $\left(\mathrm{kg} / \mathrm{mm}^{2}\right)$ & $2.54-2.60$ \\
Young's Modulus $\left(\mathrm{kg} / \mathrm{mm}^{2}\right)$ & $15-19$ \\
Thermol Expansion $\left(1 /{ }^{\circ} \mathrm{C}\right)$ & $1.8-2.0 \times 10^{4}$ \\
Thermol Conductivity $\left(\mathrm{kcol} / \mathrm{m} \cdot \mathrm{hr} \cdot{ }^{\circ} \mathrm{C}\right)$ & 5.04
\end{tabular}

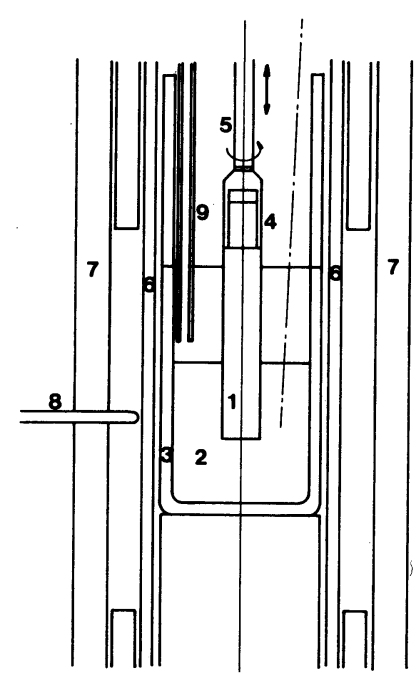

Fig. 1. Experimental equipment.

1 : Specimen, 2 : Molten iron, 3 : Crucible, $4:$ Holder, $5:$ Rod, $6: \mathrm{Al}_{2} \mathrm{O}_{3}$ pipe, $7:$ Heater, $8:$ Thermocouple, $9:$ Injection nozzle for $\mathrm{Ar}-3 \% \mathrm{H}_{2}$.

し, 30 分間, 回転保持した.この間, 必要に応じ溶鉄 のサンプリングと酸素プローブにより溶鉄中の溶解酸素 量を測定した. 実験中, 雾囲気を制御するため, 管内に $\mathrm{Ar}-3 \% \mathrm{H}_{2}$ ガスを吹き込み，更に溶鉄表面にも同じガス を吹き付けた. 30 分後, 試料を引き上げ炉内で放冷し, 試験前後の試料の半径の差から損耗量を求めた. また, 試験後の試料について, 稼働面近傍の顕微鏡及び EPMA 観察を行った.

\section{3. 結 果}

\section{1 浸漬試験結果}

図 2 に, 溶鉄中の溶解酸素量を変化させたときの $\mathrm{Si}_{3} \mathrm{~N}_{4}$ 反応焼結体の損耗量の変化を示す. 溶鉄中の溶解 酸素濃度は酸素プローブを使って測定した值で, 溶解酸 素 $\underline{\mathrm{O}}$ の活量係数を 1 としてある $\left(a_{0}=[\mathrm{wt} \%]\right)$. 溶鉄温 度: $1630^{\circ} \mathrm{C}$, 回転数 : $300 \mathrm{rpm}$, 浸漬時間 : 30 分の条件

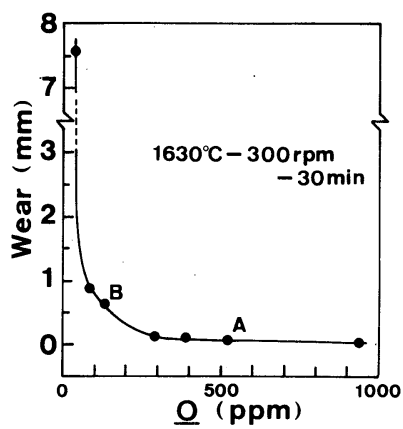

Fig. 2. Wear of reaction-bonded $\mathrm{Si}_{3} \mathrm{~N}_{4}$ vs. dissolved oxygen content.

下では, $300 \mathrm{ppm}$ 以上の高酸素領域において, $\mathrm{Si}_{3} \mathrm{~N}_{4}$ の 損耗はほとんどなく, 逆に $300 \mathrm{ppm}$ 以下の低酸素領域 において溶解酸素量の低下とともに損耗が極端に大きく なる傾向が明らかに認められる. 更に, 損耗の大きいも のについては, 浸漬中に溶鉄からの気泡の生成が観察さ れた. いずれの場合も $\mathrm{Si}_{3} \mathrm{~N}_{4}$ 反応焼結体を溶鉄に浸漬す ると, 溶鉄中の溶解酸素量の娍少が認められた. また, 浸漬後の溶鉄中の Si の増加は, 浸漬前の溶解酸素量が 300 ppm 以下の溶鉄においてのみ認められ, 溶解酸素量 が低下するにしたがって増加する傾向が見られた。

\section{2 微構造観察と EPMA}

溶解酸素量が $522 \mathrm{ppm}$ (図 2 中の A) のときの試料稼 働面の顕微鏡写真を図 3, 図 4 に, 溶解酸素量が 131 ppm (図 2 中のB）のときの試料稼働面の顕微鏡写真を 図 5 , 図6に示す.

損耗の少ない試料 (A) の稼働面には気泡や地金を巻 込んだ厚さ 50 - $150 \mu \mathrm{m}$ の比較的均質な付着層が観察さ れる.この付着層はEPMAによる分析結果からほぼ $100 \%$ に近い $\mathrm{SiO}_{2}$ であることが確認された。一方, 損 耗の大きい試料 (B) の稼働面には母材とは異なった相 が一部で認められるものの, ある厚さをもった付着層は 観察されない.この母材とは異なった相は同じく EPMA による分析から $\mathrm{SiO}_{2}$ であることが分かった. また, いずれの場合も試料中への溶鉄侵入は認められな かった.なお, 試料内部に見られる白色部分は,

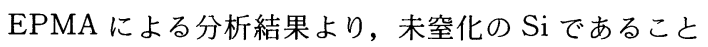
を確認した。

以上より, 溶解酸素量が高い場合, 溶鉄中の酸素と $\mathrm{Si}_{3} \mathrm{~N}_{4}$ 中の $\mathrm{Si}$ とが反応して $\mathrm{SiO}_{2}$ を生成し,これが試料 表面を覆い, その結果, この $\mathrm{Si}_{3} \mathrm{~N}_{4}$ 層が溶鉄と試料との 接触を妨げ $\mathrm{Si}_{3} \mathrm{~N}_{4}$ 反応焼結体の損耗を抑制したものと考 えられる.

\section{4. 考 察}

浸漬試験結果及び観察を基に $\mathrm{Si}_{3} \mathrm{~N}_{4}$ と溶鉄との反応機 構を主に, 熱力学的考察を用いて明らかにする.なお, 


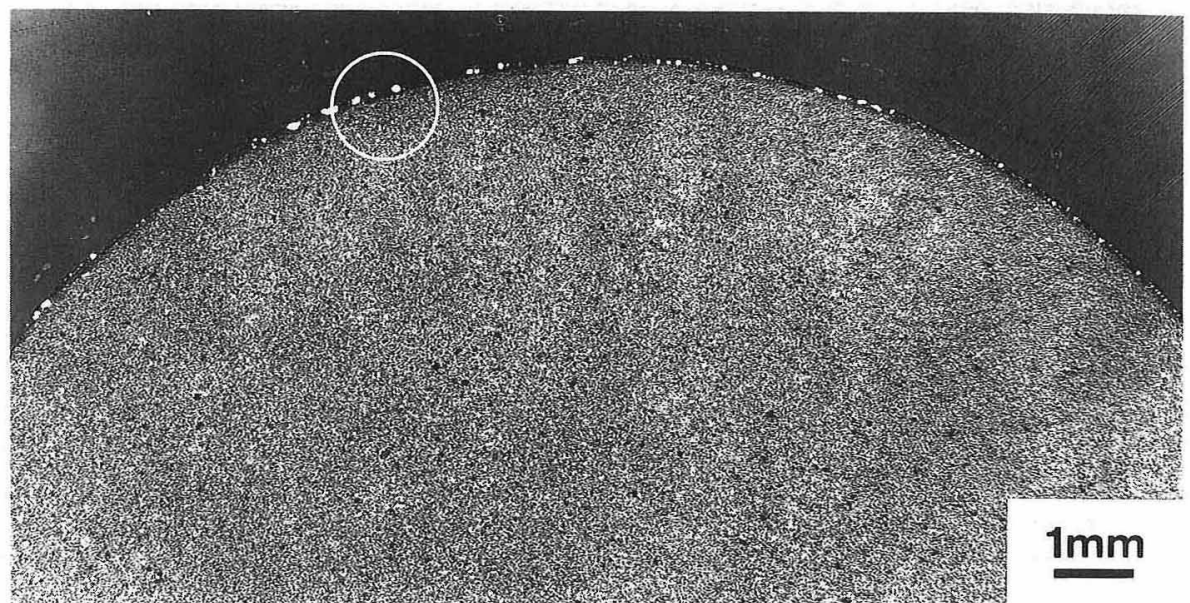

Fig. 3. Reaction-bonded $\mathrm{Si}_{3} \mathrm{~N}_{4}$ at hot face dipped in iron with 522-ppm dissolved oxygen.

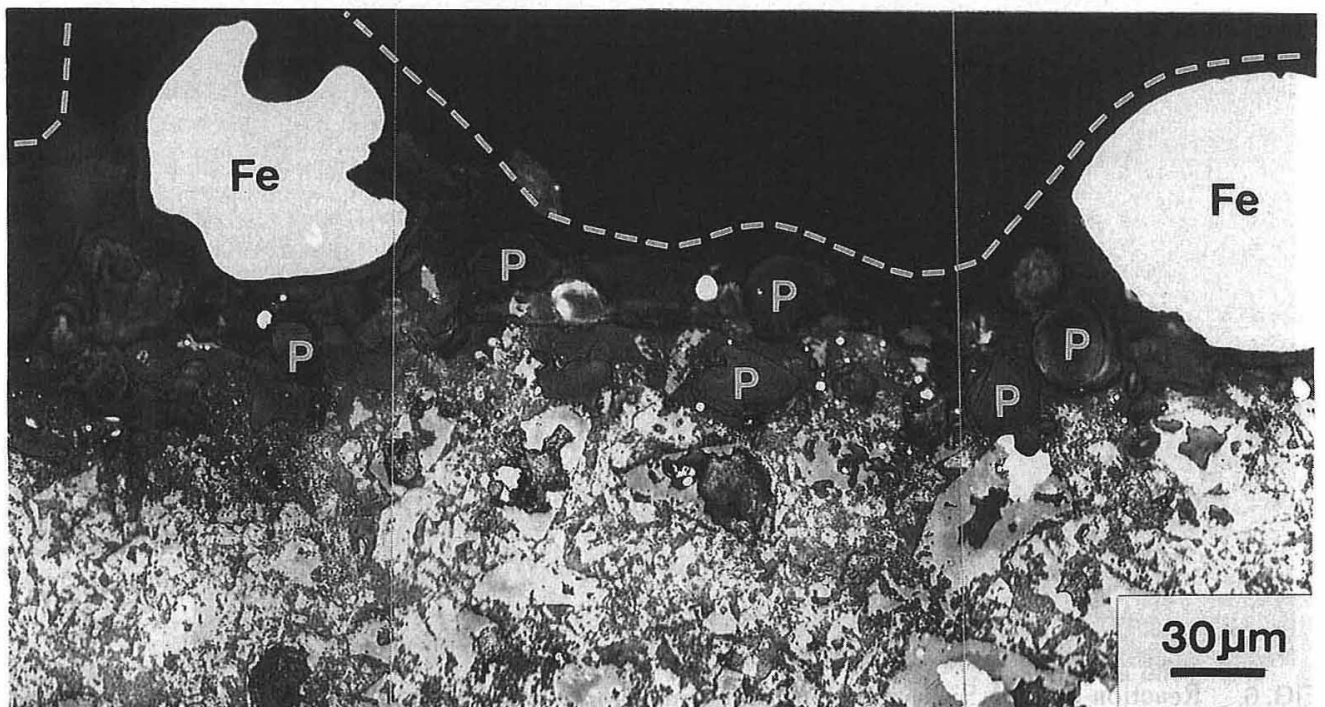

Fig. 4. Reaction-bonded $\mathrm{Si}_{3} \mathrm{~N}_{4}$ at hot face dipped in iron with 522-ppm dissolved oxygen (the portion in the circle in Fig. 3).

検討に際しては, 浸漬温度を $1627^{\circ} \mathrm{C}(1900 \mathrm{~K})$ とし， 浸漬前の溶鉄中の $\mathrm{Si}$ 濃度（分析値 $\leqq 0.01 \%$ ）を 0 と仮 定し行った.

\section{1 溶鉄に対する $\mathrm{Si}_{3} \mathrm{~N}_{4}$ の安定性}

$1627^{\circ} \mathrm{C}(1900 \mathrm{~K})$ における, 酸素分圧 $P_{\mathrm{o}_{2}}$, 窒素分圧 $P_{\mathrm{N}_{2}}$ を変化させたときの $\mathrm{Si}-\mathrm{O}-\mathrm{N}$ 系の各凝縮相の安定領 域を図 7 に示す。なお，図上部及び右側に，酸素分圧及 び窒素分圧に平衡する溶鉄中の溶解酸素濃度及び窒素濃 度を合わせて示した。この図 7 に，試験に用いた溶鉄の 溶解酸素濃度及び窒素濃度をプロットした。これより実 験に用いた溶鉄は， $\mathrm{Si}_{3} \mathrm{~N}_{4}$ が安定な領域より高酸素側及 び低窒素側に位置していることが分かる．ただし，浸漬 前の溶鉄中の酸素濃度が溶鉄中の $\mathrm{Si}$ 濃度 $(\mathrm{Si} \leqq 0.01 \%)$ によって決まっていないことから，溶鉄中の酸素濃度及
び窒素濃度を示す值が $\mathrm{SiO}_{2}$ が安定な領域にあっても, このことが直ちに $\mathrm{SiO}_{2}$ の生成を意味せず，次節の検討 が必要となる.

\section{2 反応の量的検討}

(1) $\mathrm{SiO}_{2}(\mathrm{~s})$ に平衡する溶鉄中 $\underline{\mathrm{Si}}$ 濃度之溶解酸素 $\underline{0}$

$\mathrm{SiO}_{2}(\mathrm{~s})$ に平衡する溶鉄中の $\underline{\mathrm{Si}}$ 之溶解酸素 $\underline{\mathrm{O}}$ の関係 は（1）式で表せる。ここで $\mathrm{Si}_{3} \mathrm{~N}_{4}$ 表面に生成した $\mathrm{SiO}_{2}$ を純物質 $\left(a_{\mathrm{SIO}_{2}}=1\right)$ であるとし, 以下検討する.

$$
\mathrm{SiO}_{2}(\mathrm{~s})=\underline{\mathrm{Si}}+2 \underline{\mathrm{O}}
$$

图 8 にこの $\mathrm{SiO}_{2}(\mathrm{~s})$ と平衡する溶鉄中の $\underline{\mathrm{Si}}$ 濃度と溶解 酸素 $\mathrm{O}$ の関係を示す. 図中の曲線は $\mathrm{SiO}_{2}$ の飽和溶解度 曲線に相当する. Si レベルの低い領域において 的変化が大きく，逆に高い領域においては，品の量的 


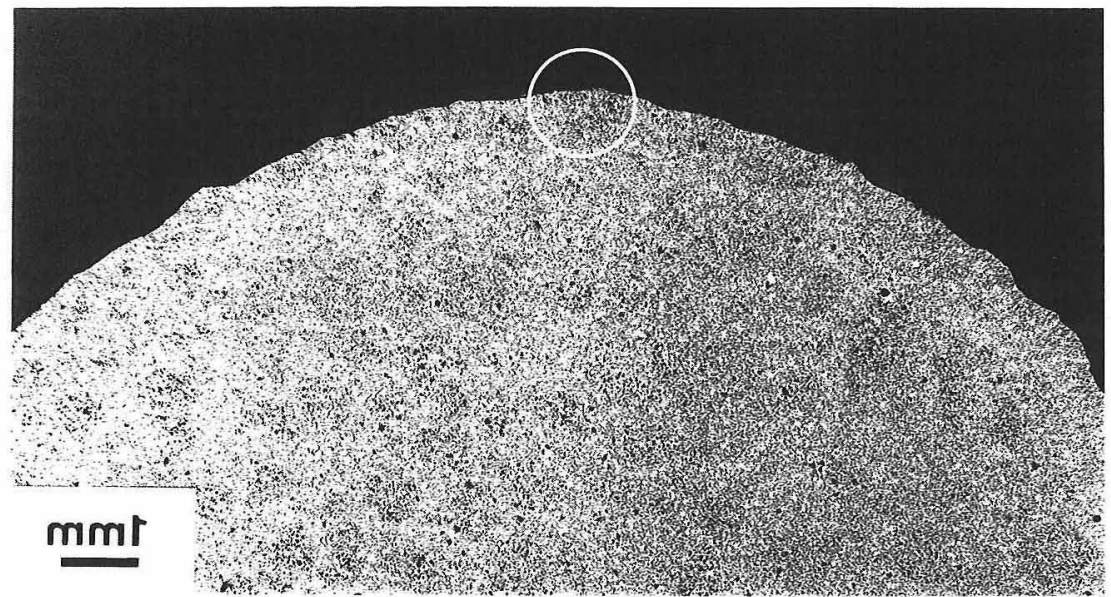

Fig, 5. Reaction-bonded $\mathrm{Si}_{3} \mathrm{~N}_{4}$ at hot face dipped in iron with 131-ppm dissolved oxygen.

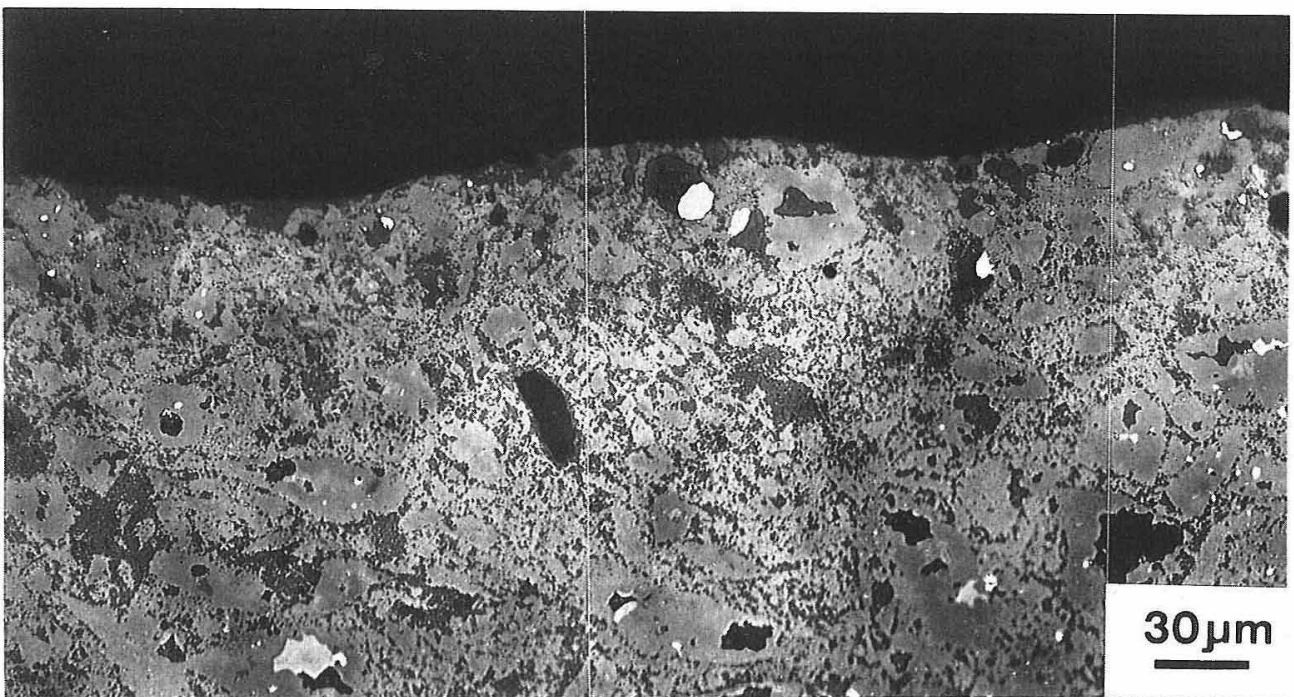

FiG.6. Reaction-bonded $\mathrm{Si}_{3} \mathrm{~N}_{4}$ at hot face dipped in iron with 131-ppm dissolved oxygen (the portion in the circle in Fig. 5).

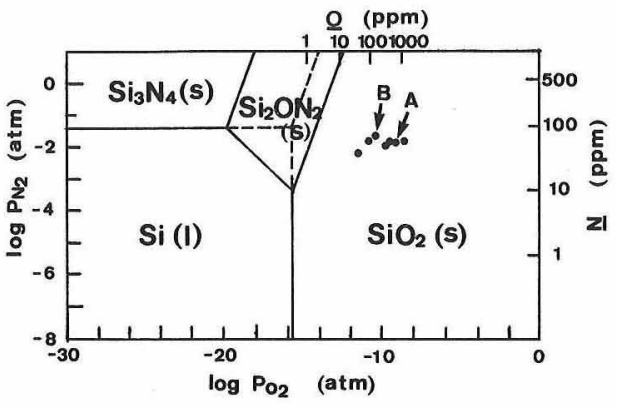

Fig. 7. Stability diagram ${ }^{7), 8)}$ in the system Si-O-N, and oxygen and nitrogen partial pressure in equilibrium with molten iron $^{9)}\left(1627^{\circ} \mathrm{C}\right), \cdots$ : metastable equilibrium.

変化が小さいことが分かる. 図中の曲線の左側の領域及 び下部は,（1）式によっては, 溶鉄中の溶解酸素は決

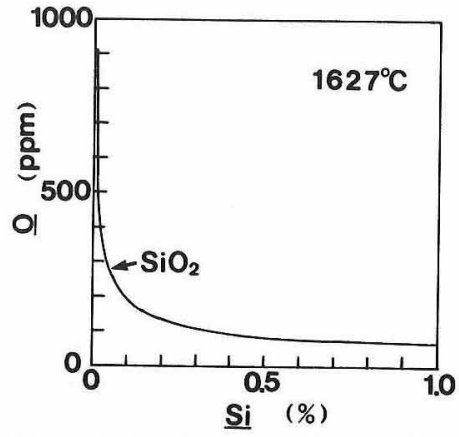

Fig. 8. The relation between dissolved oxygen and silicon in equilibrium with solid silica $\left(1627^{\circ} \mathrm{C}\right)$.

まらない. 言い換えると, この部分では, 脱酸反応は起 こらず, $\mathrm{Si}$ は単に溶鉄中に溶解し, $\mathrm{SiO}_{2}$ は生成しない. なお, 曲線の右側及び上部は $\underline{\mathrm{Si}}$ 及び $\underline{\mathrm{O}}$ の過飽和の領域 


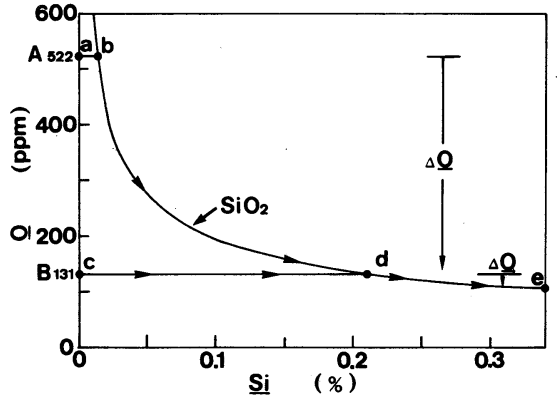

Fig. 9. Reaction paths between molten iron and $\mathrm{Si}_{3} \mathrm{~N}_{4}$. となる

（2）反応における量的変化

ここでは, 図 8 の低 Si レベルの部分を拡大した図 9 を使い, $\mathrm{Si}_{3} \mathrm{~N}_{4}(\mathrm{~s})$ の $X$ 重量部が, 溶解酸素濃度 522 $\mathrm{ppm}$ (A) 及び $131 \mathrm{ppm}$ (B) の溶鉄の 100 重量部と反 応した場合について考察する.なお， $522 \mathrm{ppm}(\mathrm{A})$ 及 び $131 \mathrm{ppm}$ (B) は酸素プローブで測定した活量である が，ここではそのまま反応前の溶解酸素の重量濃度とし て以下検討する。

(1) $552 \mathrm{ppm}$ の溶鉄と $\mathrm{Si}_{3} \mathrm{~N}_{4}$ との反応

溶解酸素量が $522 \mathrm{ppm}$ の溶鉄に $\mathrm{Si}_{3} \mathrm{~N}_{4}(\mathrm{~s})$ が接触する と ( $\mathrm{a}$ 点), まずこの酸素レベルで $\mathrm{SiO}_{2}(\mathrm{~s})$ に平衡する $\mathrm{Si}$ 濃度 $0.014 \%$ （b 点）まで $\mathrm{SiO}_{2}(\mathrm{~s})$ の生成なしに $\mathrm{Si}_{3} \mathrm{~N}_{4}(\mathrm{~s})$ の $\mathrm{Si}$ が溶鉄に溶解する (Step 1). このとき まで ( $\mathrm{a}$ 点 $\rightarrow \mathrm{b}$ 点) に消費される $\mathrm{Si}_{3} \mathrm{~N}_{4}$ 量は, 0.023 重 量部である．溶鉄中の $\mathrm{Si}$ 濃度が $0.014 \%$ になると $\mathrm{SiO}_{2}$ （s）を生成し，それ以降，（1）式の平衡を保ちながら, つまり図 9 中の曲線にしたがって $\mathrm{O}$ が減少する（b点 $\rightarrow \mathrm{e}$ 点)(Step 2).このことは, $\mathrm{Si}_{3} \mathrm{~N}_{4}(\mathrm{~s})$ 中の $\mathrm{Si}$ の一部 は溶鉄の脱酸に使われ, 残りは酸素レベルを $\mathrm{Si}-\mathrm{O}$ 平衡 を維持するために溶解することを意味する.

Step $1: \mathrm{Si}_{3} \mathrm{~N}_{4}(\mathrm{~s}) \rightarrow 3 \underline{\mathrm{Si}}+2 \mathrm{~N}_{2}(\mathrm{~g})$

Step $2: \mathrm{Si}_{3} \mathrm{~N}_{4}(\mathrm{~s})+\alpha \underline{\mathrm{O}} \rightarrow$

$$
\beta \mathrm{Si}+\gamma \mathrm{SiO}_{2}(\mathrm{~s})+2 \mathrm{~N}_{2}(\mathrm{~g})
$$

このとき生成する $\mathrm{SiO}_{2}(\mathrm{~s})$ の量は（1）式にしたがっ て変化する溶解酸素の変化量 $\Delta \mathrm{O}$ により決まる. 量的 な変化を把握するために $\mathrm{Si}_{3} \mathrm{~N}_{4}$ の重量部にして 200 倍の 溶鉄 $(\underline{O}=522 \mathrm{ppm})$ が反応したと仮定すると，つまり $X=0.5$ 重量部であるとき $\mathrm{Si}_{3} \mathrm{~N}_{4}$ (s) は $0.265 \% \underline{\mathrm{Si}}$ のと ころでなくなり，このときの $\mathrm{O}$ は $117 \mathrm{ppm}$ になる. 522 $\mathrm{ppm}$ と $117 \mathrm{ppm}$ との差から 0.076 重量部の $\mathrm{SiO}_{2}(\mathrm{~s})$ が 生成する.

(2) $131 \mathrm{ppm}$ の溶鉄と $\mathrm{Si}_{3} \mathrm{~N}_{4}$ との反応

一方, 溶鉄中の溶解酸素量が $131 \mathrm{ppm}$ の場合 (c 点), $0.213 \% \mathrm{Si}$ (d 点) まで溶解酸素量の変化及び $\mathrm{SiO}_{2}(\mathrm{~s})$ の生成なしに $\mathrm{Si}_{3} \mathrm{~N}_{4}$ (s) 中の $\mathrm{Si}$ は溶鉄に溶解し, $\mathrm{Si}$ が $0.213 \%$ まで溶解すると初めて $\mathrm{SiO}_{2}(\mathrm{~s})$ が生成する.
それ以降は, 図 9 の曲線にしたがって $\mathrm{SiO}_{2}(\mathrm{~s})$ の生成 と $\mathrm{Si}$ の溶解が同時に起こり反応していく (d 点 $\rightarrow \mathrm{e}$ 点). $X$ を同じく 0.5 重量部とした場合, $\mathrm{Si}_{3} \mathrm{~N}_{4}(\mathrm{~s})$ は $0.300 \%$ Si のところでなくなり，このときの 0 は 110 $\mathrm{ppm}$ となる. $131 \mathrm{ppm}$ と $110 \mathrm{ppm}$ との差から 0.004 重 量部の $\mathrm{SiO}_{2}$ (s) が生成する.

(3) $\mathrm{Si}_{3} \mathrm{~N}_{4}$ との反応における $522 \mathrm{ppm}$ と $131 \mathrm{ppm}$ の溶 鉄との差

$\mathrm{Si}_{3} \mathrm{~N}_{4}$ 亡溶鉄が反応した場合, 溶解酸素量が $522 \mathrm{ppm}$ の溶鉄では, Step 1 の $\mathrm{Si}_{3} \mathrm{~N}_{4}$ ，溶解反応がほとんどなく, ほぼ $\mathrm{Si}_{3} \mathrm{~N}_{4}$ の浸漬と同時に, $\mathrm{SiO}_{2}(\mathrm{~s})$ が生成する Step 2 の反応になり, かつ反応は大きな溶解酸素量の減少を 伴い, このとき多量の $\mathrm{SiO}_{2}$ を生成する. 一方, 溶解酸 素量が $131 \mathrm{ppm}$ の溶鉄の場合, $\mathrm{SiO}_{2}(\mathrm{~s})$ の生成しない Step 1 の反応が長く, $\mathrm{SiO}_{2}(\mathrm{~s})$ の生成はある程度反応 が進んでからになる. また, 生成しても溶解酸素量の減 少からみて $\mathrm{SiO}_{2}$ の生成量は $522 \mathrm{ppm}$ の溶鉄に比べると わずかである。

以上の検討から，溶解酸素量が $522 \mathrm{ppm}$ の溶鉄の場 合, 試料表面に観察された $\mathrm{SiO}_{2}(\mathrm{~s})$ 層は, $\mathrm{Si}_{3} \mathrm{~N}_{4}$ 焼結体 の溶鉄への浸漬とほぼ同時に生成した多量の $\mathrm{SiO}_{2}(\mathrm{~s})$ によりできたものと推察される. 一般に, 反応生成物を 介して行われる反応では, 反応速度は, 反応生成物内の 拡散速度及び厚さに依存し ${ }^{10)}$, 特に $\mathrm{Si}_{3} \mathrm{~N}_{4}$ 表面に生成し た $\mathrm{SiO}_{2}$ 層のように反応生成物が固相である場合, その 反応速度は極端に低下する．したがって，いったんでき た $\mathrm{SiO}_{2}(\mathrm{~s})$ 層は見掛け上 $\mathrm{Si}_{3} \mathrm{~N}_{4}$ の保護層として働いた もの5)と考えられる．事実，酸素プローブで測定した実 験後の溶解酸素量は $522 \mathrm{ppm}$ から $393 \mathrm{ppm}$ に減少して おり，このとき生成した $\mathrm{SiO}_{2}(\mathrm{~s})$ 量から， $\mathrm{Si}_{3} \mathrm{~N}_{4}$ 焼結体 表面の $\mathrm{SiO}_{2}$ の厚さを計算すると $99 \mu \mathrm{m}$ となる．この值 は，顕微鏡観察結果亡良く一致する．このときの試験後 の溶鉄中の $\mathrm{Si}$ の増加は分析限界ぎりぎりであり, 分析 結果からは Si の増加は認められない.

一方, 溶解酸素量が $131 \mathrm{ppm}$ の溶鉄に浸漬した場合, 試料表面に $\mathrm{SiO}_{2}$ 層が認められなかった理由は，この低 酸素レベルでは, $\mathrm{SiO}_{2}$ の生成なしに $\mathrm{Si}$ が溶解し, 生成 してもごくわずかであることより説明できる. 試料の損 耗量から, 計算した Si 量の増加（浸漬後の $\mathrm{Si}$ 濃度） は $0.17 \%$ と, 吸い上げサンプルによる溶鉄の分析結果 の $0.14 \%$ とほぼ一致する.この段階では, 先に検討し たように Step 1 の反応による領域で, $\mathrm{SiO}_{2}$ の生成はな いことになる.

\section{3 溶解窒素量の変化}

$\mathrm{Si}_{3} \mathrm{~N}_{4}(\mathrm{~s})$ に平衡する溶鉄中の $\mathrm{Si}$ と溶解窒素 $\mathrm{N}$ の関 係は（4）式で表せる.

$$
\mathrm{Si}_{3} \mathrm{~N}_{4}(\mathrm{~s})=3 \underline{\mathrm{Si}}+4 \underline{\mathrm{N}}
$$

この $\mathrm{Si}_{3} \mathrm{~N}_{4}(\mathrm{~s})$ が存在するときの $\mathrm{Si}$ と $\mathrm{N}$ の溶解度積は 
熱力学デー夕から計算すると, $[\% \mathrm{Si}]^{3} \cdot[\% \mathrm{~N}]^{4}=$ $0.2723 \times 10^{6}$ となる．この溶解度積の值は，非常に大き な値であり, 実験の条件である大気圧下では $\mathrm{Si}_{3} \mathrm{~N}_{4}(\mathrm{~s})$ が溶鉄中に平衡下で存在できないことを示している.

このことは, $\mathrm{Si}_{3} \mathrm{~N}_{4}$ 焼結体を浸漬したとき $\mathrm{Si}_{3} \mathrm{~N}_{4}$ 中の 窒素は, 一部は溶鉄に吸窒され, 残りは気泡となって溶 鉄表面から放出されることを意味する，その結果，溶鉄 中の溶解窒素濃度は増加し, 動的平衡として $1 \mathrm{~atm} の$ $\mathrm{N}_{2}$ 分圧に平衡な溶解窒素濃度である $471 \mathrm{ppm}$ に近づく. 溶鉄の分析結果では，低酸素レベルの溶鉄に 30 分間浸 漬した後のトータル N 濃度は $40 \sim 60 \mathrm{ppm}$ のレベルから 250〜350 ppm に増加している.

\section{4. $4 \mathrm{SiO}_{2}$ 保護層}

以上検討してきたように，溶解酸素量が高い溶鉄の場 合，反応により $\mathrm{Si}_{3} \mathrm{~N}_{4}$ 焼結体表面に生成する $\mathrm{SiO}_{2}$ 層が 保護層として働くことを見てきた. しかし，この $\mathrm{SiO}_{2}$ 層において，熱履歴等によるき裂が発生した場合には， $\mathrm{SiO}_{2}$ 層は，もはや保護層として働かず，溶鉄と内部の $\mathrm{Si}_{3} \mathrm{~N}_{4}$ 焼結体亡の間で, 気相を介した反応が進行す る $^{4), 6)}$ ものと考えられる，一方，外来性のアルカリ酸化 物，例えば精錬用あるいは鋳造用フラックスからの $\mathrm{Na}_{2} \mathrm{O}$ などによる $\mathrm{SiO}_{2}$ 層のガラス化は, 反応生成物層 内の拡散速度を増加させ，この場合も結果として，保護 層としての役割を低下させる5)と考えられる.

\section{5. 総 括}

$\mathrm{Si}_{3} \mathrm{~N}_{4}$ 反応焼結体と溶鉄との反応における溶鉄中の溶 解酸素量の影響について, 実験炉による $\mathrm{Si}_{3} \mathrm{~N}_{4}$ 焼結体の 浸漬試験，それに続く顕微鏡及び EPMA 観察，更に熱
力学的な検討を行った.

その結果， $\mathrm{Si}_{3} \mathrm{~N}_{4}$ の損耗は，溶鉄中の溶解酸素量に大 きく影響され，酸素量が多いほど損耗が小さく，酸素量 が少ないほよ゙損耗が大きくなることが明らかになった。 $522 \mathrm{ppm}$ に代表される高酸素レベルにおいては，溶鉄と $\mathrm{Si}_{3} \mathrm{~N}_{4}(\mathrm{~s})$ の反応は試料の浸漬とほぼ同時に多量の $\mathrm{SiO}_{2}$ （s）を生成することから，表面に溶鉄との接触を妨げる 保護層を作り，結果的に $\mathrm{Si}_{3} \mathrm{~N}_{4}$ 焼結体の損耗を抑制する. 一方，131 ppm に代表される低酸素レベルでは，当初， 反応は $\mathrm{SiO}_{2}(\mathrm{~s})$ の生成なしに $\mathrm{Si}$ の溶解が起こり，その 後 $\mathrm{SiO}_{2}(\mathrm{~s})$ が生成しても量的にわずかであることから 保護層を形成できず，結果的に反応は起こり続け $\mathrm{Si}_{3} \mathrm{~N}_{4}$ 焼結体は損耗する。

\section{文献}

1）石沢健喜，白仁田 昭，石原 剛，品川技報，24，91-98 (1980).

2）萇輪 晋, 小坂岑雄, 名古屋工業技術試験所報告, 15 , 131-37 (1966).

3) 小坂岑雄, 加藤 誠, 山田 守, 高柳 猛, 蓑輪 晋, 名古屋工業技術試験所報告，16，72-79（1967）。

4) 前田榮造, 新谷宏隆, 川上辰男, 岸高 寿, 窯協, 88, 523-31 (1980).

5) G. Ervin, J. Am. Ceram. Soc., 41, 347-52 (1958).

6) E. A. Gulbransen and S. A. Jansson, Oxid. Metals, 4, 181-201 (1972).

7) D.R. Stull and H. Prophet, "JANAF Thermochemical Tables, Second Edition" (1971).

8) W. R. Ryall and A. Muan, Science, 165, 1363-64 (1969).

9）日本学術振興会製鋼第 19 委員会編；“製鋼反応の推奨平 衡値, 改定增補” (1984).

10) W. D. Kingery, H. K. Bowen and D. R. Uhlmann, "Introduction to Ceramcs, 2 nd ed.", John Wiley \& Sons, Inc., New York (1976). 